SOTER 2014.51(79)

ISSN 1392-7450 (Print), ISSN 2335-8785 (Online)

http://dx.doi.org/10.7220/2335-8785.51(79).1
TEOLOGIJA IR FILOSOFIJA

Algirdas GAIŽUTIS

Lietuvos edukologijos universitetas

\title{
Arkivyskupas Mečislovas Reinys - neotomistinės filosofijos pradininkas Lietuvoje
}

\begin{abstract}
Straipsnyje analizuojama arkivyskupo Mečislovo Reinio dvasinio ir pasaulietinio išsilavinimo eiga. Ji lèmé platų europietinị būsimojo arkivyskupo kultūrinị akiratị, gilụ teologijos, filosofijos, psichologijos, pedagogikos dalykų išmanymą. Tyrinèjamas esminis jo pasaulèžvalgos posūkis nuo Tomo Akviniečio interpretacijų neotomistinès filosofijos linkui. Ypač pabrěžiami M. Reinio nuopelnai plètojant neotomistinę filosofiją Lietuvoje.

The author of the article explores Archbishop Mečislovas Reinys' developmental process of his spiritual and secular education which had had a considerable impact on the future-to-be archbishop's European cultural world view, and profound knowledge of such subjects as Theology, Philosophy, Psychology and Pedagogy. Special attention is paid to the main turn in the Archbishop's world view marked by the shift from the interpretations by St. Thomas Aquinas towards Neo-Thomistic philosophy. M. Reinys' contribution to the development of Neo-Thomism in Lithuania has been also highlighted in the article.
\end{abstract}

\section{Ivadas}

Tyrimo tikslas - atskleisti arkivyskupo Mečislovo Reinio nuopelnus diegiant ir plètojant Lietuvoje neotomistinę mintị. Straipsnio autorius naudoja kelis metodus: tekstologinị, istorini lyginamąji, aprašomąji.

Darbe nagrinėjamas $M$. Reinio įnašas ị neotomistinès filosofijos sklaidą Lietuvoje. M. Reinys nebuvo vienintelis jos pradininkas, tiksliau - vienas iš pirmuju ir nuosaikiausiuju. Tačiau jubiliejinio pranešimo (straipsnio) pavadinimas yra korektiškas. Aišku, neotomistiniu idèju atgarsiu aptinkama ir kitu to meto teologu, filosofu darbuose - Adomo Jakšto-Dambrausko, pal. Jurgio Matulaičio, Jono Mačiulio-Maironio, Prano Kuraičio. Autoriui rūpi gilintis ił M. Reinio, kaip teologo ir filosofo, pedagogo ir psichologo, pasaulèžvalgos formavimosi ypatumus bei sąlygas. Nagrinejjami tik keli epizodai, susiję su M. Reinio universitetinėmis studijomis, kurios turẻjo didelę reikšmę jo asmenybès brendimui ir likimui. Tomo Akviniečio autoriteto ir jo mokymo naujos interpretacijos arkivyskupą ne tik domino, tenkino smalsumą, bet ir tapo nuolatiniu svarstymų dalyku. Taigi M. Reinys savo raštais, straipsniais ne tik prisidejjo prie tomistinès filosofijos formavimosi Lietuvoje, bet ir skatino šios įtakingos krikščioniškosios minties bei idèjų sklaidą, platesnę diskursinę erdvę. 


\section{Dvasinis ir pasaulietinis M. Reinio išsimokslinimas}

M. Reinys - mokslininkas, pedagogas, profesorius, visuomenės veikëjas (buvęs Lietuvos Respublikos užsienio reikalų ministras), kankinys paliko neišdildomą pėdsaką Lietuvos dvasiniame gyvenime. Jo knygos, studijos, šimtai straipsnių sudaro didžiulị palikimą ${ }^{1}$, kurị būtina kuo greičiau susisteminti ir išleisti raštus - jie galètų sudaryti 5-6 tomus. Tai turètų būti intelektualų pareiga.

M. Reinys - plataus išsilavinimo žmogus. Gamtos apdovanotas didžiais talentais, dar turejjo stiprią kūrybinę valią ir tai, ką klasikiniai filosofai vadino sapientia - išmintimi. Šių savybių neprarado metams bėgant ir skausmingai keičiantis gyvenimo sąlygoms. Jo gyvenimas liudija siekimą mokslo ir šviesos, buvimą drauge su Kitais ir atsakomybę už Kitus. Būtina priminti kelias arkivyskupo biografijos detales.

M. Reinys 1899 m. aukso medaliu baigè Aleksandro III gimnaziją Rygoje, mokèsi Vilniaus kunigu seminarijoje, vẻliau studijavo Petrapilio dvasineje akademijoje, susidomejjo prof. Pranciškaus Būčio skaitomu apologetikos kursu. 1909 m. už darbą „Krikščionybès pasirodymas daug prisidejjo prie dorovès kilimo“, parašytą lotynų kalba, gavo teologijos magistro laipsnị.

Jau ị̌sventintas kunigu, 1909-1913 m. studijas tęsẻ Belgijoje, Aukštajame filosofijos institute prie Luveno universiteto. Ten studijavo filosofiją, teologiją, psichologiją ir kitas disciplinas: fiziką, chemiją, geologiją-minerologiją, biologiją, anatomiją, fiziologiją ir politinę ekonomiją. Iš viso 17 disciplinų. Be to, dar lankẻ paskaitas ir Gamtos mokslų fakultete, kur išklausė ir išlaikè botanikos, zoologijos, citologijos dalykų egzaminus. Gamtos mokslais nuodugniai domejjosi ir vèliau. M. Reinio įsitikinimu, jie glaudžiai susiję su teologija bei filosofija.

Būtent Aukštajame filosofijos institute atsiskleidè M. Reinio talentas ir kūrybinès galios. Čia jis parašè bei apgynè disertaciją "Vladimiro Solovjovo dorovès pagrindai“ (prancūzų kalba) ir igijo filosofijos daktaro laipsnị. Tai buvo pirmoji lietuvio disertacija apie rusų filosofą, teologą, poetą Vladimirą Solovjovą. Vèliau disertaciją apie ji apgynė ir Stasys Šalkauskis. To meto lietuviams intelektualams V. Solovjovo idejos turèjo didelę reikšmę. M. Reiniui, kaip ir daugeliui, darè ịspūdị V. Solovjovo mintys apie krikščioniškają valstybę, kurioje vidinis žmogaus pasaulis būtų kuo mažiau suvaržytas, o žmonių egzistencijai ir tobulejimui sudarytos palankiausios sąlygos.

M. Reinys gerai žinojo ir savitai interpretavo vadinamąą V. Solovjovo „laisvają teosofiją“ - teologijos, filosofijos ir mokslo vienybės ideją kaip visuomenès visuotinès vienybès, dievažmogiškosios asmenų sajungos pagrindą. Teosofija - „dieviškoji išmintis“ reiškia sintezę mokslo atradimų ir krikščioniškosios religijos, Dievo apreikštų tiesų atverties, taigi vientiso žinojimo apie pasaulį, kuriame gyvena ir veikia žmogus. Tikèjimas papildo protą siekiant giliai suprasti Dievo kūrinị ir pasitikèti Dievo autoritetu². Šias idèjas V. Solovjovas plačiai paskleidè savo „Paskaitose apie dievažmogiškumą“ (1877-1881), veikaluose „Teokratijos istorija ir ateitis“ (1885-1887), „Gèrio pateisinimas“ (1897-1899) ir kt.

Luveno universitetas, kur apgynė disertaciją, M. Reiniui nebuvo tik institucija, pripažinusi jo nuopelnus, - Aukštajame filosofijos institute brendo neotomistinès filosofijos srovè ir idejos. 
Neotomizmas (vadinamoji naujoji scholastika) Vatikano oficialiai pripažintas 1879 m. - popiežiaus Leono XIII enciklikoje „Aeterni patris“ paskelbtas oficialia katalikybès filosofija. Žymiausi jos atstovai Prancūzijoje buvo Étienne’as Gilsonas, Jacques’as Maritaine’as; Belgijoje - kardinolas Désiré’as-Josephas Mercier, Louis de Raeymaekeris, Fernandas van Steenberghenas ir kt. Visgi būtent Aukštasis filosofijos institutas turèjo didžiausią reikšmę populiarinant neotomizmo idejjas. Žinoma, prie to prisidejo ir kiti: Šv. Tomo akademija Vatikane, ịvairūs katalikiškieji institutai Paryžiuje, Milane ir kituose miestuose. Tačiau šiam institutui, kaip teigia Władysławas Tatarkiewiczius ${ }^{3}$, priklauso didžiausi nuopelnai. Jo profesūra propagavo universaliąsias idèjas: tikejjimo ir proto sintezès, įžvalgos ir empiriškumo, kontempliacijos ir prakticizmo, tikinčiujų individualybės ir bendrystès. Tai esminių teologinių postulatų - Dievo atverties ir jo ieškojimų - tąsa. Šios idèjos buvo skleidžiamos ir Strasbūro universitete - jo Teologijos fakultete būsimasis arkivyskupas studijavo 1913-1914 m., gilinosi ị apologetiką, klausẻ garsiojo profesoriaus Alberto Lango paskaitų. Išmokęs 9 užsienio kalbas, M. Reinys studijose ir raštuose rèmési plačiu istoriniu ir kultūriniu žmogiškosios patirties kontekstu, ịvairiais jo šaltiniais, aišku, pradedant teologija ir baigiant gamtamoksliu. Taigi jis buvo, kaip dabar sakytume, fundamentalaus, sisteminio, o ne „mozaikiško“ išsilavinimo žmogus; kaip ir dera teologui, kunigui - imlus dvasinès kultūros siekiams ir naujovèms. Tad ir neotomistinès idejjos jam darè didelę ịtaką.

\section{Reinys - Tomo Akviniečio interpretatorius, neotomistas}

Neotomizmas - itin sudètinga filosofijos tèkmé, dariusi įtaką personalizmui, egzistencinei filosofijai, „religijos fenomenologijai“. Kard. D.-J. Mercier ragino atsigręžti į Tomą Akvinieti (kaip ir Tomas Akvinietis rèmèsi Aristoteliu, iš dalies - Platonu, šv. Augustinu) ir svarstyti aktualias Apreiškimo tiesų, dievoieškos, dabarties žmogaus egzistencijos problemas. Nors Tomas Akvinietis ir laikè filosofiją teologijos tarnaite, bet pagrinde būtiną teologijos, filosofijos, gamtos mokslų sąsają, galimas jungtis ir sąveiką. „Teologijos sąvade“ rašè: „Niekas nekliudo, kad tuos pačius dalykus, kuriuos tyrinejja filosofijos mokslai tiek, kiek gali pažinti prigimtinis protas, kartu tyrinètų ir kitas mokslas tiek, kiek galima pažinti per dieviškajj apreiškimą. Tai rodo, jog teologija, priklausanti šventajam mokymui, savo prigimtimi skiriasi nuo tos teologijos, kuri laiko save sudedamąja filosofijos dalimi." "T Tokią nuostatą ypač vertino kard. D.-J. Mercier ir jo mokiniai Armandas Thiéry, Maurice’as de Wulfas, Désiré Nys.

Pastarasis autorius ypač imponavo M. Reiniui. D. Nys dèstė kosmologiją, psichologiją, laiko ir erdvès, dinamikos, atomizmo, energetizmo, hilomorfizmo ir kitus kursus. D. Nys įrodinejjo, kad su gamta supažindina gamtos mokslai, filosofija pagilina gamtos pažinimą visomis prigimtomis dvasios priemonèmis, teologija supažindina su antgamtiniu, Dievo apreikštu mokslu. Be to, D. Nys buvo geras lietuvių studentų (Pijaus Bielskio, Jurgio Galdiko ir kt.) bičiulis. 1909 m. jis pašventino ịkurtos draugijos „Lietuva“ vèliavą, pasakè įspūdingą kalbą, lietuviams Luveno universitete leido ịsirengti atskirą skaityklą - to neturejo jokios kitos tautybès studentai. Tai istorinis faktas, pagarbos ženklas Lietuvos valstybei - pavergtai ir pažemintai carinès Rusijos ${ }^{5}$. 
M. Reiniui perspektyvus atrodè neotomizmui būdingas universalizmas, aristoteliškujų-tomistinių prielaidų patikimumas. Mokslas nèra pasaulio pažinimo, būties atvèrimo aktų papildinys. Pagrindinès tiesos, būties ir egzistencijos esiniai neatveriami tik eksperimentais ir pažinimu, žmogiškasis intelektas privalo derèti su Dievo atvertimi, dieviškuoju intelektu, dievoieška ir dievostata. Ypač trijų esmingiausių žmogaus santykių su visuomene - individualizmo, kolektyvizmo ir solidarumo - kontekste. Pirmaisiais abejojama kaip kraštutiniais ir būtent solidarumas labiausiai vertintinas, nes grindžiamas krikščioniškuoju artimo meilès principu. Dèl neotomistų idejjų katalikiškoji teologija, eschatologija tapo modernesnè ir atviresnè naujai žmogaus istorinei patirčiai, siekiant tobulesnio bendruomeninio, socialinio gyvenimo.

Neotomistinès M. Reinio nuostatos kilo iš jo teologinès ir filosofinès pasaulèžiūros. Laikui bėgant tik sustiprèjo ir atsispindejo arkivyskupo veikaluose ir straipsniuose, o svarbiausia - kasdieniuose bei pastoraciniuose sielovados darbuose. Dera paminèti nors dalị jo veikalų: tai studijos „Tomas Akvinietis: jo gyvenimas, raštai ir metodas“ (1916), „Paskirstomoji teisybe்“ (1937), „Rasizmo problema“ (1939); studija „Žinojimas ir tikejjimas“, paskelbta per daugelị „Ateities“ numerių; moksliniai straipsniai, publikuoti žurnale „Logos“: „Fizinè ir psichinè realybe்“ (1922); „Sielos sąvoka mūsų laikų psichologijoj“ (1923); „Priežastingumo klausimu“ (1923); „Kantas ir Dievo ịrodymų kritika“ (1924); „Šv. Augustino psichologinès pažiūros: mokslo sintezès keliais“ (1935); „Dvasinès būties problema“ (1937); „Religijos psichologijos vaizdas“ (1932) ir dešimtys kitų.

Ir šiandien svarbu panagrinèti, kaip M. Reinys aiškino ir interpretavo Tomo Akviniečio filosofinę sistemą. Arkivyskupas buvo detaliai susipažinęs su svarbiausiais teologų ir filosofų darbais, tai patvirtina jo studija „Tomas Akvinietis: jo gyvenimas, raštai ir metodas“. M. Reinys pažymi, kad Anzelmo Kenterberiečio, Aleksandro iš Halès, Alberto Didžiojo, Bonaventūros, Tomo Akviniečio, Jono Dunso Skoto, šv. Augustino ir kitų idejjas būtina suaktualinti, padaryti šiandienos dvasinio gyvenimo sudedamąja dalimi. M. Reinys teigè, jog viduramžiai dar menkai žinomi, vis dèlto Lietuvos kontekste scholastinès filosofijos autoritetai buvo aiškūs. Tomistinès idejos vienų darbuose persipindavo su škotistinėmis, pastarosios - su okamistinėmis ir t. t. XVI-XVIII a. gyvavusi scholastika buvo europietiška, iš esmès išlaikiusi klasikinės scholastikos problematiką, metodiką ir Aristotelio veikalų komentavimo formą ${ }^{6}$. Ryškų vaidmenị čia suvaidino Dominikonų ordinas. Anot Romano Plečkaičio, „Akviniečio doktrina tapo visuotinai priimtina dominikonų mokyklose“"7.

M. Reinio studijoje atskleidžiama, kaip dominikonas Tomas Akvinietis siekė aukštumų įvairiuose Italijos, Prancūzijos universitetuose, kaip polemizavo su Aristotelio komentatoriaus ir panteistiškojo (ypač pomirtinio gyvenimo klausimu) filosofo Averojaus sekejjais ir netgi svarstè kai kurias šv. Augustino idejjas.

M. Reinys žavejosi Tomo Akviniečio, kaip asmenybės, žmogiškuoju paprastumu ir natūralumu. M. Reinys teigia, kad abstraktus mokslo darbas neatšaldè Tomo Akviniečio religinių ịsitikinimų, jie atsispindejjo jo elgesyje, kuo giliausiame maldingume, giliame tikejjimo gerbime, skaistybeje. Tomui Akviniečiui buvo aišku, kad dorovinis sugedimas visada aptemdo protą, kliudo eiti prie tiesos ir ypač antgamtinio pažinimo. Tomo Akviniečio asmenyje šventasis ir mokslo vyras sudarè tikrą, darnią vienovę. M. Reinio manymu, tai galètų būti įvairių pažiūrų teisingumo kriterijus. Tokia Tomo 
Akviniečio laikysena tapo M. Reiniui jo gyvenimo kelrodžiu, kuriuo remdavosi sudètingiausiomis, dramatiškiausiomis gyvenimo situacijomis.

Kaip ir dera, M. Reinys žavejosi tobulu Tomo Akviniečio veikalu „Summa theologiae“. Šiame fundamentaliame veikale bei kituose polemizuojama ir remiamasi literatūros klasikais Ovidijumi, Aristofanu, Horacijumi, Ciceronu, istorikais Julijumi Cezariu, Saliustijumi, Titu Livijumi, filosofais Platonu, Aristoteliu, Demokritu, Heraklitu, stoikais, neoplatonikais, pirmaisiais scholastikais (X a.), žydų ir arabų filosofais (XIXII a.), Šventuoju Raštu, Bažnyčios tèvais (ne mažiau kaip 50-ia jų), santarybų nutarimais, Romos teisdaryste, kanonų teise, teologais ir kt.

M. Reinys atskleide, kaip Tomas Akvinietis, ypač remdamasis Aristotelio veikalais, iškèlè patyrimo ir mokslinio pažinimo reikšmę, gamtos dalykų pažinimo svarbą. Jis pabrèžè Dievo duotojo Apreiškimo tiesų galimumą ir sutiko jas priimti, jei tikètinumas bus ịrodytas. Tai išties esminis teologijos mokslo uždavinys. Tomui Akviniečiui buvo aišku: filosofija ir teologija turi savo specifiką, autoritetus, skirtumus, bet jos gali viena kitą sustiprinti, keldamos esmingiausius klausimus: Dievo, žmogaus sielos nemarumo, laisvès, prigimtinès žmogaus dorovès, apreikštų tiesų pažinimo ir supratimo. Savo ruožtu teologija papildo filosofiją žiniomis iš Šventojo Rašto, bažnytinès tradicijos ir prigimtinių žmogaus pažinimo šaltinių. Šventojo Rašto egzegezès, homiletikos ir liturgikos dalykai papildo filosofų idejjas. Šv. Augustinas yra pasakęs įsidèmètinus žodžius veikale „Apie Dievo valstybę“: „Tikras filosofas myli Dievą.“8

M. Reiniui, kaip neotomistui, Tomo Akviniečio, vadinamojo Doctor Angelicus, palikimas buvo kaip atskaitos taškas gilinantis i žmogaus vidinio pasaulio ir bendruomeniškumo gelmę bei fenomenologiją, to pasaulio suderinamumą su metafizika. Būsimasis arkivyskupas samprotavo: Dievo esmei, jo šventenybei išreikšti anaiptol nepakanka panteizmo (nors jis gali būti patrauklus, gražus), stabmeldiško antropomorfizmo ir moderniškojo simbolizmo.

M. Reiniui ypač svarbus atrodė požiūrio ị Apreiškimo tiesas intelektinis pobūdis. Dievo Apreiškimo faktai galimi pagrịsti istoriškai ir giliu tikejjimu, per pažinimo galią ir kūrybą, propaguojant artimo meilę ir visą gyvenimą gryninant bei tobulinant nepabaigiamą savo paties asmenị ir individualybės paiešką. M. Reiniui atrodè prasminga tai, kad „neotomizmas (neoscholastika) imasi ne tik gaivinti Tomą, bet ir reformuoti ji, kiek tai išrandama reikalingu po šešių amžių darbo filosofijos srityje ${ }^{\text {“9 }}$. Juoba kad Tomas Akvinietis buvo ịsitikinęs aristotelizmo ypatinga svarba teologijai, ji ne tik genialiai permąstè, bet ir tinkamai modifikavo. Dabar reikia, pirma, kuo nuodugniau istoriškaigenetiškai ištirti scholastiškus paties Tomo Akviniečio šaltinius, išnagrinèti idẻjų kilmę, apsvarstyti jo ịtaką vèlesniems laikams. Antra, perkainoti Tomo Akviniečio idejju turinị ir formą. Tokius du uždavinius, anot M. Reinio, ir stengiasi atlikti neotomizmas ${ }^{10}$.

Tomo Akviniečio idejos turèjo didžiulę įtaką ne tik M. Reinio neotomistinei veiklai, kūrybai, tematikai, rašymo stiliui, bet ir formavo arkivyskupo pasaulěžiūrą. M. Reiniui rūpejo ir ontologinè, gnoseologine tomizmo bei neotomizmo problematika, ir socialinis Bažnyčios vaidmuo, stiprinant krikščioniškosios bendruomenès ryšius Lietuvoje bei pasaulyje. Jis ieškojo būdų, kaip sustiprinti valstybės pagrindus ir užtikrinti prigimtines žmogaus teises bei laisves. 
M. Reini domino ir socialinè Tomo Akviniečio doktrina. Žmogus yra socialinė būtybè, gimsta šeimoje, ji yra esminis valstybès elementas, taigi pati žmogaus prigimtis skatina įsitraukti $\mathfrak{i}$ socialines grupes. Tomas Akvinietis aiškino, kad socialinès grupès ir valstybės turi dvejopą tikslą. Pirma, turi užtikrinti interesų pusiausvyrą, sugyvenimą, ramybę (Tomas Akvinietis remiasi šv. Augustino mintimis). Antra, turi užtikrinti dorovę ir materialinès gerovès igijimą (Tomas Akvinietis remiasi Aristoteliu). Tačiau Tomui Akviniečiui rūpejjo ne tik šie siekiniai. Valstybès ir visuomenès sutvarkymas, anot jo, neišvengiamai reikalauja viena ar kita forma išreikštos valdžios buvimo. Apskritai valdžios autoritetas eina iš Dievo, bet nevalia daryti išvados, kad valstybès vadovai esą Dievo parinktieji ar ịvairių institucijų įstatymai savaime yra teisingi, idealūs ${ }^{11}$.

Minètoje studijoje M. Reinys teigia, kad tiesos siekis padare didelę itaką Tomo Akviniečio raštų turiniui ir formai, pirmiausia kalbai:

Tomo raštų kalba paprasta, aiški, išreikšta su dideliu griežtumu, sistemingai sutvarkyta. Šitie kalbos privalumai jau savaime brangintini, igauna mùsų laikais dar didesnę vertę, nes šiandieną turim progą pamatyti jų kontrastą, visą anarchiją dabartinès filosofiškosios terminologijos, kur žaidžiama žodžiais, nesiskaitant su ju precizija, o kai kada net lengva širdimi manoma išrišti painius klausimus naujai sudarytais terminais, vietoj dalyką aiškinančios priežasties nurodant vien tuščius žodžius. ${ }^{12}$

M. Reinio visuomeninè bei valstybinè veikla, jo, kaip kunigo, pasišventimas skleisti Kristaus mokymą yra geriausias pavyzdys dabarčiai. Tai pavyzdys „Tauriojo Ganytojo meilès ir ištikimybės aukštiesiems Evangelijos idealams" ${ }^{\text {"13 }}$.

Jonas Paulius II 1993 m. rugsèjo 4 d. Vilniaus arkikatedroje bazilikoje taip kalbėjo apie palaimintaji Jurgị Matulaiti, vyskupą Julijoną Steponavičių ir arkivyskupą M. Reini, suimtą 1947 m. ir mirusị kankinio mirtimi 1953 m. Rusijoje, Vladimiro kalejime: „Ju gyvenimas yra padrąsinimas ir parama Lietuvos Bažnyčiai“, nes jie „su tokia didvyriška ištikimybe savo gyvenimą pašvente Evangelijai?!“14

Vokiečių diplomatas, mokslų daktaras Gottholdas Starke, kartu su M. Reiniu kalejęs Vladimiro kalëjime, rašè: „Jo laikysena yra tikro Bažnyčios šventojo laikysena. Jo autoritetas sklido pro kalëjimo sienas iš vienos griežtai izoliuotos celès kiton. Aš pats gavau daug iš šios prakilnios asmenybès, kurioje jungèsi tvirtas tikèjimas, didelis mokslas, krikščioniškoji meilè ir nusižeminimas. ${ }^{\text {"15 }}$

\section{Išvados}

1. Būtina susisteminti M. Reinio rašytini palikimą ir išleisti jo raštus. Jie liudytu šios asmenybès veiklos bei kūrybos mastą.

2. M. Reinio veikalai atspindi jo visapusišką, sisteminị išsilavinimą - ne tik kaip teologo, bet ir kaip filosofo, psichologo, pedagogo. Tai leidžia kalbèti apie M. Reini kaip apie europinès kultūros žmogu, kuriam nepriimtinas provincialus uždarumas, tolerancijos stoka ir esminių krikščioniškujų vertybių sureliatyvinimas.

3. M. Reinys gali būti laikomas vienu iš neotomistinès filosofijos pradininkų Lietuvoje. Šią itin brandžią mąstymo, kūrybos, dvasingos bendruomeninès veiklos kryptị puoselejo ano meto filosofai ir teologai: Stasys Šalkauskis, Pranas Dovydaitis, Jonas Juodelis, Juozapas Čepenas, Juozas Lomanas ir kiti. 


\section{NUORODOS}

1 Reinys Mečislovas // Lietuviu enciklopedija. Bostonas: Lietuviu enciklopedijos leidykla. 1961. T. 25. P. 84-87; Arkiv. M. Reinio raštų bibliografija // Arkivyskupas Mečislovas Reinys. Chicago: Lietuvių krikščionių demokratų sąjunga. 1977. P. 235-245.

2 Мыслители, изменившие мир, от Аристотеля до Юнга. Москва: ЭКСМО. 2012. С. 318.

3 Tatarkiewicz W. Historia filozofii. Tom trzeci. Warszawa: PWN. 1970. S. 238.

4 Tomas Akvinietis. Teologijos sąvadas // Filosofijos istorijos chrestomatija. Viduramžiai. Vilnius: Mintis. 1980. P. 409.

5 Mečislovas Reinys. Prof. D. Nys // Židinys. 1927. Nr. 9. P. 154-156.

6 Valatka $V$. Pirmasis filosofinio ugdymo Lietuvoje etapas: tarp scholastikos ir naujojo mokslo // LOGOS. 2013. Nr. 77. P. 32.

7 Plečkaitis R. Lietuvos filosofijos istorija. T. 1. Viduramžiai. Renesansas. Naujieji amžiai. Vilnius: Kultūros, filosofijos ir meno institutas. 2004. P. 54.

8 Augustinas Aurelijus. Apie Dievo valstybę // Filosofijos istorijos chrestomatija. Ten pat. P. 120.

9 Reinis M. Tomas Akvinietis: jo gyvenimas, raštai ir metodas. Kaunas: Šv. Kazimiero draugija. Banaičio spaustuvè. 1916. P. 25.

10 Ten pat. P. 26.

11 Ten pat. P. 22

12 Ten pat. P. 9.

13 Kun. Jonas Jurgaitis. Tiesos keliu. Vilnius: ENKO. 1992. P. 370.

14 Šventojo Tèvo kalba Vilniaus arkikatedroje bazilikoje kunigams, vienuoliams, vienuolèms ir klierikams. Vilnius. 1993 m. rugsèjo 4 d. // LOGOS. 1994-1995. Nr. 9. P. 55.

15 Aleksa K. P. Arkivysk. M. Reini prisimenant // Aidai. 1954. Nr. 10. P. 442-445.

\section{LITERATŪRA IR ŠALTINIAI}

1. Aleksa K. P. Arkivysk. M. Reini prisimenant // Aidai. 1954. Nr. 10. P. 442-445.

2. Arkiv. M. Reinio raštų bibliografija // Arkivyskupas Mečislovas Reinys. Chicago: Lietuviu krikščionių demokratų sąjunga. 1977. P. 235-245.

3. Augustinas Aurelijus. Apie Dievo valstybę // Filosofijos istorijos chrestomatija. Viduramžiai. Vilnius: Mintis. 1980. P. 120-129.

4. Kun. Jonas Jurgaitis. Tiesos keliu. Vilnius: ENKO. 1992.

5. Mečislovas Reinys. Prof. D. Nys // Židinys. 1927. Nr. 9. P. 154-156.

6. Plečkaitis R. Lietuvos filosofijos istorija. T. 1. Viduramžiai. Renesansas. Naujieji amžiai. Vilnius: Kultūros, filosofijos ir meno institutas. 2004.

7. Reinis M. Tomas Akvinietis: jo gyvenimas, raštai ir metodas. Kaunas: Šv. Kazimiero draugija. 1916.

8. Reinys Mečislovas // Lietuviu enciklopedija. Bostonas: Lietuvių enciklopedijos leidykla. 1961. T. 25. P. 84-87.

9. Šventojo Tèvo kalba Vilniaus arkikatedroje bazilikoje kunigams, vienuoliams, vienuolems ir klierikams. Vilnius. 1993 m. rugsèjo 4 d. // LOGOS. 1994-1995. Nr. 9.

10. Tatarkiewicz W. Historia filozofii. Tom trzeci. Warszawa: PWN. 1970.

11. Tomas Akvinietis. Teologijos sąvadas // Filosofijos istorijos chrestomatija. Viduramžiai. Vilnius: Mintis. 1980. P. 408-441.

12. Valatka V. Pirmasis filosofinio ugdymo Lietuvoje etapas: tarp scholastikos ir naujojo mokslo // LOGOS. 2013. Nr. 77. P. 29-39.

13. Мыслители, изменившие мир, от Аристотеля до Юнга. Москва: ЭКСМО. 2012.

Gauta: 20140910 
Algirdas GAIŽUTIS

\section{ARCHBISHOP MEČISLOVAS REINYS - THE FOUNDING FATHER OF NEO-THOMISTIC PHILOSOPHY IN LITHUANIA}

\section{S u $\mathrm{m}$ m a $r$ y}

The article explores the contribution of the Archbishop Mečislovas Reinys to the dissemination of Neothomistic Philosophy in Lithuania. Abp. M. Reinys was not the only author of Neo-thomistic Philosophy, but one of the first and reasonable ones. However, the title of the article is considered to be correct. The author is interested in peculiarities of and conditions for the world-view formation of the great theologian and philosopher, educator and psychologist Abp. M. Reinys. Only few episodes are being explored, that are related with Abp. M. Reinys' university studies, which had a great and invaluable significance to the development of his personality and fate. The archbishop was not only interested in the authority and modern interpretations of the teaching of St. Thomas Aquinas, it also satisfied his curiosity and became the subject of his continuous considerations. Thus, his writings and articles not only contributed to the development of the thomistic Philosophy in Lithuania, but also inspired and encouraged the dispersion of this Christian thought and ideas and its broader discursive spread.

PAGRINDINIAI ŽODŽIAI: Mečislovas Reinys, Tomas Akvinietis, neotomistinè filosofija, teologijos ir filosofijos sąveika, krikščioniškoji antropologija, tikejjimas ir laisvè.

KEY WORDS: Mečislovas Reinys, Thomas Aquinas, Neo-thomistic philosophy, interaction of theology and philosophy, Christian anthropology, faith and freedom.

Algirdas GAIŽUTIS - humanitarinių mokslų habilituotas daktaras, profesorius, akademikas, Lietuvos edukologijos universiteto rektorius. Adresas: Studentų g. 39, 08106 Vilnius. El. paštas rektoratas@leu.lt.

Algirdas GAIŽUTIS - Habilitated Doctor of Humanities, Professor, Academician, Rector of the Lithuanian University of Educational Sciences. Address: Studentų str. 39, 08106 Vilnius. E-mail: rektoratas@leu.lt. 